\title{
ANALISIS TINGKAT PEMAHAMAN AKUNTANSI (STUDI MAHASISWA JURUSAN AKUNTANSI FEB UNTAN)
}

\author{
Sukma Indra* \\ Universitas Tanjungpura \\ Sari Rusmita \\ Universitas Tanjungpura
}

\begin{abstract}
The research is aimed at observing the comprehension level of accounting students in accounting course, the class program and gender. Purposive sampling was used as the sampling technique, in which the students who had taken PA1, PA2, AKM1 and AKM2 courses were the research sample. The hypothesis was answered by one sample T-Test to assess the comprehension level of accounting students, while One Way ANOVA was employed to examine the possible difference of students in Regular A, PPAPK and International classes in comprehending accounting course. Furthermore, independent sample test was used to observe the comprehension level based on gender. There were three research findings. First, there is a different comprehension level of accounting students in accounting department of all programs, namely Regular A, PPAPK and International classes. It might be caused by the quality of different student input, because they have different entrance on every program. Second, there is no difference in comprehension level of accounting students based on gender.
\end{abstract}

Keywords: accounting, comprehension of accounting, students

\section{PENDAHULUAN}

Pendidikan akuntansi di Indonesia telah mengalami perubahan mendasar sejak awal tahun 1990-an (Machfoedz, 1999). Meskipun demikian Sundem (1993) dalam Machfoedz (1999) mengkhawatirkan akan ketidakjelasan industri akuntansi yang dihasilkan oleh pendidikan tinggi akuntansi. Dikhawatirkan pendidikan tinggi tidak sanggup membuat anak didiknya menguasai dengan baik pengetahuan dan keterampilan (karena yang diajarkan cuma menghapal). Bahkan sekolah yang elite pun tidak mampu lagi membekali murid-muridnya dengan pengetahuan dan pegangan yang memadai untuk menghadapi tantangan zaman ini (Harefa, 2000).

Prakarsa (1996) mengkritisi pendidikan tinggi akuntansi karena lulusannya kurang memiliki keterampilan dan orientasi profesional yang diperlukan guna mengimplementasikan pengetahuan yang diserap dalam dunia nyata. Kelemahan tersebut diperparah karena peserta didik kurang mendapat pendidikan yang memadai dalam

\footnotetext{
*Korespondensi: Sukma Indra, Jurusan Ilmu Ekonomi dan Studi Pembangunan, Fakultas Ekonomi dan Bisnis, Universitas Tanjungpura, Jalan Prof. Dr. H. Hadari Nawawi Pontianak 78124. Email: sukma.indra28@yahoo.com
} 
keterampilan intelektual, komunikasi, serta interpersonal. McClelland (1997) dalam (Goleman, 2000) menyatakan bahwa kemampuan akademik bawaan, nilai rapor, dan prediksi kelulusan pendidikan tinggi tidak dapat memprediksi seberapa baik kinerja seseorang sudah berkerja atau seberapa tinggi sukses yang dicapainya dalam hidup. Sebaliknya ia menyatakan bahwa seperangkat kecakapan khusus seperti empati, disiplin diri, dan inisiatif mampu membedakan orang sukses dari mereka yang berprestasi biasabiasa saja.

Terdapat perbedaan kondisi fisik dan psikis antara laki-laki dan perempuan. Menurut Jagtenberg dan D'Alton (1995) dalam Martono, Nanang, Mintarti, \& Rostikawati (2009) "gender and sex are not the same thing. Gender specifically refers to the social meanings attached to biological differences. ... The way we see ourselves and the way we interact are affected by our internalization of values and assumptions about gender". Perbedaan gender dalam pendidikan dapat terjadi dalam perolehan prestasi belajar. Prestasi belajar adalah taraf keberhasilan siswa dalam mempelajari materi pelajaran di sekolah yang dinyatakan dalam bentuk skor yang diperoleh dari hasil tes mengenai sejumlah materi pelajaran tertentu (Abdullah, 2008 dalam Mirawati, 2015). Dalam penelitian Pirmohamed, Debowska, \& Boduszek (2017) menemukan sebuah metode untuk meningkatkan prestasi akademik mahasiswa laki-laki dan perempuan yang ada di perguruan tinggi. Sementara itu, Zoghi, Kazemi, \& Kalani (2013) dalam penelitiannya menemukan bahwa mahasiswa perempuan lebih baik prestasinya dari pada mahasiswa laki-laki.

Dunia usaha saat ini mendorong kebutuhan tenaga kerja yang mampu menyusun laporan keuangan. Untuk menghasilkan laporan keuangan yang dapat diandalkan diperlukan pemahaman yang benar dalam penyusunan laporan keuangan. Penyusunan laporan keuangan di Indonesia harus sesuai dengan Standar Akuntansi Keuangan (SAK). Untuk memperoleh suatu pengetahuan terhadap teori akuntansi yang mendasar maka diperlukan pengetahuan akan dasar-dasar akuntansi agar pengetahuan tersebut dapat dijadikan pegangan semua praktik akuntansi. Pengetahuan akuntansi diajarkan di perguruan tinggi terkesan sebagai pengetahuan yang hanya berorientasikan kepada mekanisme secara umum saja, sangat jauh berbeda apabila dibandingkan dengan praktik yang dihadapi di dunia kerja (Sari'i, Irsadsyah, \& Nasrullah, 2010). Menurut Budhiyanto \& Nugroho (2004), tingkat pemahaman akuntansi mahasiswa dinyatakan dengan seberapa mengerti seorang mahasiswa terhadap apa yang sudah dipelajari yang dalam konteks ini mengacu pada mata kuliah akuntansi dan Indeks Prestasi Kumulatif (IPK). Tanda seorang mahasiswa memahami akuntansi tidak hanya ditujukan dari nilai-nilai yang didapatkannya dalam mata kuliah tetapi juga apabila mahasiswa tersebut mengerti dan dapat menguasai konsep-konsep yang terkait.

Pada semester awal, setiap perguruan tinggi mewajibkan mahasiswa jurusan akuntansi untuk mengikuti perkuliahan mata kuliah yang berkaitan dengan dasar akuntansi. Mata kuliah ini memegang peranan penting dan menentukan tingkat 
pemahaman mahasiswa yang akan mempelajari akuntansi dan mata kuliah lain yang berkaitan pada tahapan berikutnya. Sebagai mata kuliah pengantar, mata kuliah ini dimaksudkan untuk memberikan pengetahuan dasar atau fundamen kepada para mahasiswa. Salah satu mata kuliah tersebut adalah Pengantar Akuntansi. Mata kuliah ini diharapkan agar mahasiswa dapat memahami konsep dasar akuntansi secara baik. Tingkat pemahaman akuntansi merupakan sejauh mana kemampuan untuk memahami akuntansi baik sebagai seperangkat pengetahuan (body of knowledge) maupun sebagai proses atau praktik. Secara umum, penguasaan pengetahuan atau keterampilan yang dikembangkan oleh mata pelajaran, lazimnya ditunjukkan dengan nilai tes atau angka yang diberikan oleh guru/dosen (Muliono dalam Hanifah \& Abdullah, 2001).

Terdapat beberapa penelitian yang membahas tentang pemahaman akuntansi terhadap mahasiswa. Aditya (2011); Biduri (2016); Kusuma \& Bangun (2011); Machfoedz (1999); Mawardi (2011); Novius (2010); Rusmita (2012); Sari'i et al. (2010) melihat perbedaan pemahaman akuntansi mahasiswa berdasarkan asal sekolah menengah mahasiswa. Budhiyanto \& Nugroho (2004) meneliti pemahaman akuntansi dilihat dari mata kuliah Pengantar Akuntansi dan IPK. Trisniwati \& Suryaningsum (2003) meneliti tentang pengaruh kecerdasan emosional terhadap tingkat pemahaman akuntansi. Pendekatan yang digunakan pada penelitian-penelitian terdahulu adalah pendekatan kuantitatif untuk menguji seberapa besar pemahaman akuntansi mahasiswa. Pengukuran pemahaman akuntansi mahasiswa pada setiap penelitian berbeda-beda. Demikian juga pada penelitian ini, pemahaman akuntansi mahasiswa dilihat dari nilai yang diperoleh mahasiswa dalam menyelesaikan mata kuliah akuntansi dasar. Penelitian ini bertujuan untuk mengetahui tingkat pemahaman mahasiswa berdasarkan evaluasi hasil perkuliahan (nilai mata kuliah). Penelitian ini termotivasi dari Suwardjono (1992) yang menyatakan nilai yang diperoleh peserta didik mempunyai fungsi ganda, sebagai ukuran keberhasilan peserta didik dalam mempelajari mata kuliah dan sekaligus sebagai alat evaluasi keberhasilan mata kuliah itu sendiri.

Fokus penelitian ini adalah untuk mengetahui perbedaan pemahaman akuntansi mahasiswa Program Reguler A, Program PPAPK dan Program Kelas Internasional yang ada di FEB UNTAN. Pemahaman akuntansi diukur berdasarkan nilai matakuliah yang dicapai oleh mahasiswa dalam mempelajari suatu matakuliah. Penelitian ini berbeda dengan penelitian sebelumnya, seperti yang dilakukan oleh Rusmita (2012) yang melihat pemahaman akuntansi berdasarkan asal sekolah. Selain itu, akan melihat perbedaan tingkat pemahaman akuntansi mahasiswa yang ada di FEB UNTAN berdasarkan gendernya. Hasil penelitian ini diharapkan dapat memberikan umpan balik bagi perguruan tinggi untuk dapat menghasilkan akuntan berkualitas. Penelitian ini dilakukan sebagai sarana untuk menguji calon akuntan, apakah output yang dihasilkan oleh perguruan tinggi ini benar-benar seorang yang berkualitas yang dicerminkan dengan tingkat pemahaman akuntansi. 


\section{KAJIAN LITERATUR}

Pengetahuan akuntansi dipandang dari dua sisi pengertian yaitu sebagai pengetahuan profesi (keahlian) yang dipraktekkan di dunia nyata dan sekaligus sebagai suatu disiplin pengetahuan yang di ajarkan di perguruan tinggi. Akuntansi sebagai objek pengetahuan di perguruan tinggi, akademisi memandang akuntansi sebagai dua bidang kajian yaitu bidang praktik dan teori. Bidang praktik berkepentingan dengan masalah bagaimana praktik dijalankan sesuai dengan prinsip akuntansi. Bidang teori berkepentingan dengan penjelasan, deskripsi, dan argument yang dianggap melandasi praktik akuntansi yang semuanya dicakup dalam suatu pengetahuan yang disebut teori akuntansi (Suwardjono, 1992). Selain itu, beliau juga menyatakan akuntansi merupakan seperangkat pengetahuan yang luas dan komplek. Cara termudah untuk menjelaskan pengertian akuntansi dapat dimulai dengan mendefinisikannya. Akan tetapi, pendekatan semacam ini mengandung kelemahan. Kesalahan dalam pendefinisian akuntansi dapat menyebabkan kesalahan pemahaman arti sebenarnya akuntansi. Akuntansi sering diartikan terlalu sempit sebagai proses pencatatan yang bersifat teknis dan prosedural dan bukan sebagai perangkat pengetahun yang melibatkan penalaran dalam menciptakan prinsip, prosedur, teknis, dan metoda tertentu.

The Institute of Chartered Accountant in Australia (ICAA) dan Accounting Education Change Comission (AECC) yang dibentuk di Amerika Serikat menyatakan bahwa pendidikan akuntansi setidaknya harus dapat mempersiapkan peserta didik untuk mulai dan mengembangkan keanekaragaman karier profesional dalam bidang akuntansi. Untuk itu diperlukan tidak semata-mata pengetahuan bisnis dan akuntansi, tetapi juga penguasaan ketrampilan intelektual, interpersonal dan komunikasi serta orientasi professional (Trisniwati \& Suryaningsum, 2003).

Dalam hal tertentu, nilai yang diperoleh mahasiswa merupakan indikator keberhasilan mahasiswa dalam memahami suatu ilmu. Penguasaan pengetahuan atau keterampilan yang dikembangkan oleh mata pelajaran, lazimnya ditunjukkan dengan nilai tes atau angka yang diberikan oleh guru/dosen (Muliono dalam Hanifah \& Abdullah, 2001). Nilai yang diperoleh peserta didik mempunyai fungsi ganda, sebagai ukuran keberhasilan peserta didik dalam mempelajari mata kuliah dan sekaligus sebagai alat evaluasi keberhasilan mata kuliah itu sendiri (Suwardjono, 1991: 157 dalam Hanifah \& Abdullah, 2001).

Temuan dari hasil penelitian (Aditya, 2011; Biduri, 2016; Rusmita, 2012) samasama menunjukkan terdapat perbedaan pemahaman konsep dasar akuntansi yang signifikan antara mahasiswa yang berasal dari SMA jurusan IPS dan SMK jurusan Akuntansi. Aditya (2011) yang menyatakan terdapat perbedaan pemahaman konsep dasar akuntansi yang signifikan antara mahasiswa yang berlatar belakang pendidikan SMA-IPA dan SMK, sejalan dengan hasil dari penelitian Biduri dan berbeda dengan hasil penelitian Rusmita (2012) yang mengatakan sebaliknya. Selanjutnya hasil penelitian Aditya (2011) menemukan tidak ada perbedaan pemahaman konsep dasar 
akuntansi yang signifikan antara mahasiswa yang berasal dari SMA jurusan IPA dan SMA jurusan IPS, ini sejalan dengan temuan penelitian dari Mawardi, (2011); Novius (2010); Rusmita (2012); Sari'i et al., (2010).

Penelitian Budhiyanto \& Nugroho (2004) membahas tentang tingkat pemahaman akuntansi mahasiswa yang diukur dari seberapa mengerti seorang mahasiswa terhadap apa yang sudah dipelajari yang dalam konteks ini mengacu pada mata kuliah akuntansi dan Indeks Prestasi Kumulatif (IPK). Berbeda dengan Trisniwati \& Suryaningsum (2003) yang meneliti tentang pengaruh kecerdasan emosional terhadap tingkat pemahaman akuntansi, dengan hasil penelitian ternyata ada pengaruh kecerdasan emosional yang terdiri dari pengenalan diri, pengendalian diri, motivasi, empati, dan keterampilan sosial. Dalam penelitian ini secara berurutan mempunyai pengaruh positif terhadap pemahaman akuntansi adalah motivasi dan pengendalian diri, sedangkan pengaruh negatif ditunjukkan oleh keterampilan sosial, pengendalian diri, dan empati.

Berdasarkan hasil penelitian terdahulu memotivasi peneliti untuk melihat perbedaan pemahaman akuntansi mahasiswa dari sudut yang berbeda yaitu berdasarkan program perkuliahan dan gender dari mahasiswa. Pendekatan yang digunakan pada penelitian ini adalah kuantitatif, untuk mengetahui pemahaman akuntansi mahasiswa berdasarkan nilai matakuliah akuntansi dasar dari program perkuliahan yang berbeda dan berdasarkan gender mahasiswa. Penelitian ini menggunakan analisis One Way ANOVA dan Independent sampel test. Adapun kerangka konseptual dari penelitian ini adalah sebagai berikut :

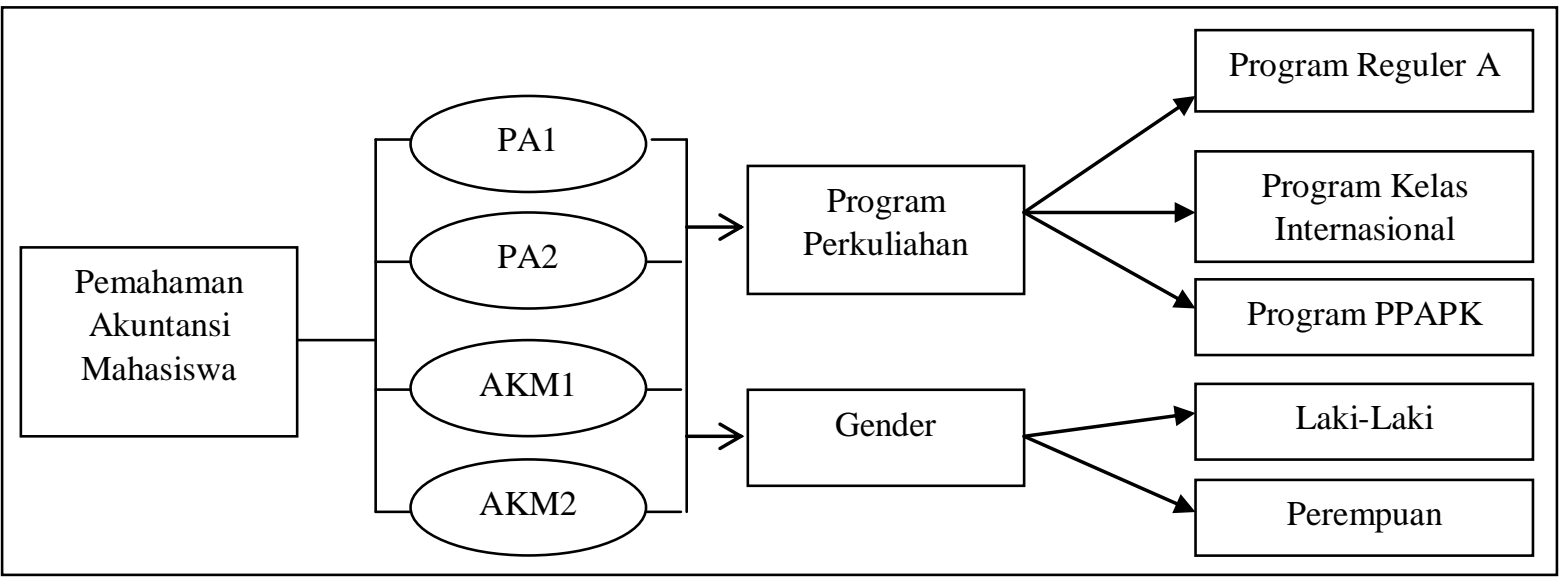

Gambar 1. Kerangka Konseptual

\section{METODA PENELITIAN}

Penelitian ini adalah penelitian deskriptif, dimana peneliti akan menggambarkan objek yang diteliti sesuai dengan fakta-fakta yang ada saat ini, lalu dianalisis dan diinterprestasikan. Populasi penelitian ini adalah mahasiswa FEB UNTAN dan teknik pengambilan sampel menggunakan metode purposive sampling. Selain itu, sampel juga 
harus memenuhi kriteria sebagai mahasiswa akuntansi angkatan tahun masuk 2013 dan sudah menyelesaikan atau mengambil mata kuliah PA 1, PA 2, AKM 1 dan AKM 2 di lingkungan FEB UNTAN baik dari Program Regular A, Program Kelas Internasional maupun Program PPAPK. Selanjutnya, yang dijadikan ukuran dan indikator tingkat pemahaman akuntansi mahasiswa diambil dari nilai-nilai mata kuliah PA 1, PA 2, AKM 1 dan AKM 2.

Pengumpulan data salah satunya untuk menjawab dugaan sementara dari peneliti dan untuk mengetahui apakah dugaan peneliti benar atau tidak maka perlu dilakukan pengujian terhadap hipotesis. Analisis data dimulai dengan memisahkan nilai-nilai matakuliah akuntansi dasar berdasarkan program perkuliahan dan berdasarkan gender lalu dilakukan uji beda untuk mengetahui apakah terdapat perbedaan atau tidak sehingga dapat menjawab hipotesis yang ada. Hipotesis dalam penelitian ini menggunakan uji One Way ANOVA untuk menguji ada atau tidak perbedaan pemahaman akuntansi dilihat dari mahasiswa Reguler A, PPAPK dan Kelas Internasional dan Independent sampel test untuk menguji apakah ada atau tidak perbedaan pemahaman mahasiswa terhadap akuntansi berdasarkan gender.

Adapun hipotesis yang akan diuji adalah sebagai berikut:

$\mathrm{H}_{\mathrm{a} 1}$ : Terdapat perbedaan tingkat pemahaman akuntansi mahasiswa dari Program Reguler A, Program PPAPK dan Program Kelas Internasional yang ada di FEB UNTAN

$\mathrm{H}_{\mathrm{a} 2}$ : Terdapat perbedaan tingkat pemahaman akuntansi mahasiswa berdasarkan gender

\section{HASIL PENELITIAN DAN PEMBAHASAN}

\subsection{Statistik Deskriptif}

Sampel penelitian ini adalah mahasiswa jurusan akuntansi angkatan tahun masuk 2013 baik dari Program Regular A, Kelas Internasional maupun PPAPK, yang sudah mengambil mata kuliah Pengantar Akuntansi 1 (PA 1), Pengantar Akuntansi 2 (PA 2), Akuntansi Keuangan Menengah 1 (AKM 1) dan Akuntansi Keuangan Menengah 2 (AKM 2). Jumlah populasi penelitian ini ada sebanyak 274 mahasiswa namun terseleksi secara alami menjadi 232 mahasiswa. Seleksi alami terjadi dikarenakan mahasiswa yang memiliki nilai E berarti tidak dapat dijadikan sampel karena mereka tidak masuk dalam kriteria sebagai sampel yang mengharuskan mereka lulus untuk semua mata kuliah akuntansi dasar tersebut. 
Tabel 1. Karakteristik Sampel

\begin{tabular}{clcccc}
\hline No & \multicolumn{1}{c}{ Program } & Laki - Laki & Perempuan & Jumlah & Persen \\
\hline 1 & Kelas Internasional & 7 & 6 & 13 & 5.6 \\
2 & Reguler A & 38 & 56 & 94 & 40.5 \\
3 & PPAPK & 39 & 86 & 125 & 53.9 \\
\hline & Total & $\mathbf{8 4}$ & $\mathbf{1 4 8}$ & $\mathbf{2 3 2}$ & $\mathbf{1 0 0 . 0}$
\end{tabular}

Sumber: FEB Untan, 2017

232 mahasiswa yang menjadi sampel terdiri dari 84 mahasiswa berjenis kelamin laki-laki dan 148 mahasiswa yang berjenis perempuan dari tiga program yang ada di lingkungan FEB Untan yaitu Program Kelas Internasional sebanyak 13 mahasiswa (5,6 persen), Program Regular A sebanyak 94 mahasiswa (40,5 pesen) dan Program PPAPK sebanyak 125 mahasiswa (53,9 persen). Jumlah mahasiswa di program PPAPK lebih banyak dibanding program lainnya untuk angkatan tahun masuk 2013. Sementara itu, berdasarkan gender mahasiswa bergender perempuan lebih banyak dibandingkan dengan laki-laki.

Tabel 2 menggambarkan tingkat pemahaman mahasiswa akuntansi berdasarkan hasil proses belajar mengajar pada masa kuliah yang berkaitan dengan mata kuliah akuntansi dasar seperti Pengantar Akuntansi 1 (PA 1), Pengantar Akuntansi 2 (PA 2), Akuntansi Keuangan Menengah 1 (AKM 1) dan Akuntansi Keuangan Menengah 2 (AKM 2). Dilihat dari nilai mean (rata-rata) mata kuliah AKM1 menunjukkan bahwa mata kuliah tersebut paling dipahami oleh mahasiswa karena rata-rata nilai dari mata kuliah ini adalah 76.09, dapat dikategorikan dalam nilai yang memuaskan. Sementara itu, tingkat pemahaman akuntansi mahasiswa yang masih rendah adalah pada mata kuliah PA 2, dengan rata-rata nilai hanya sebesar 67.53. Namun secara keseluruhan, empat mata kuliah yang dijadikan indikator pemahaman akuntansi dasar mahasiswa, nilai rata-rata mahasiswa tidaklah termasuk kategori yang tidak memuaskan karena rata-rata nilai keempat mata kuliah yang dijadikan indikator adalah sebesar 72,07 yang masih termasuk dalam kategori memuaskan.

Tabel 2. Statistik Deskriptif Tingkat Pemahaman Akuntansi Mahasiswa

\begin{tabular}{clcccc}
\hline No & \multicolumn{1}{c}{ Mata Kuliah } & Nilai Min. & Nilai Maks. & Mean & Std. Deviasi \\
\hline 1 & Peng. Akuntansi 1 (PA1) & 50.00 & 96.90 & 73.68 & 10.68 \\
2 & Peng. Akuntansi 2 (PA2) & 47.00 & 92.00 & 67.53 & 10.97 \\
3 & Ak. Keu. Menengah 1 (AKM1) & 44.09 & 97.00 & 76.09 & 9.68 \\
4 & Ak. Keu. Menengah 2 (AKM2) & 37.88 & 95.00 & 71.93 & 9.15 \\
\hline
\end{tabular}

Sumber: FEB Untan, 2017

Mata kuliah PA1 yang merupakan mata kuliah akuntansi dasar pertama diterima mahasiswa pada semester satu memiliki nilai terendah sebesar 50 sedangkan nilai 
tertinggi sebesar 96,90 dengan rata-rata nilai yang diperoleh mahasiswa sebesar 73,68. Ini bisa dikarenakan pada semester awal materi yang diterima oleh mahasiswa masih ada kaitannya atau materinya berkaitan dengan materi yang pernah diterimanya di bangku SMA. Lain halnya dengan mata kuliah PA 2 rata-rata nilai mahasiswa mengalami penurunan yaitu sebesar 67,53 dengan nilai terendah sebesar 47,00 dan nilai tertinggi sebesar 92,00. Penurunan nilai rata-rata tersebut bisa dikarenakan materi yang diterima mahasiswa pada semester kedua sudah mulai bervariasi dan lebih mendalam. Selanjutnya, dalam menerima materi tentang AKM 1 dan AKM 2 mahasiswa lebih fokus. Ini dapat dilihat dari nilai mata kuliah AKM 1 dan AKM 2 relatif sama baik dari nilai rata-rata yang masing-masing sebesar 76,09 dan 71,93 dengan masing-masing nilai tertinggi 97,00 dan 95,00 serta masing-masing nilai terendah 44,09 dan 37,88.

Tabel 3. Rekapitulasi Jumlah Mahasiswa Berdasarkan Nilai Mata Kuliah (dalam orang)

\begin{tabular}{crcccc}
\hline \multirow{2}{*}{ No } & \multirow{2}{*}{ Mata Kuliah } & \multicolumn{5}{c}{ Nilai Mata Kuliah } \\
\cline { 3 - 6 } & & A & B & C & D \\
\hline 1 & PA1 & 89 & 56 & 73 & 14 \\
2 & PA2 & 36 & 75 & 64 & 57 \\
3 & AKM1 & 93 & 85 & 51 & 3 \\
4 & AKM2 & 59 & 93 & 60 & 20 \\
\hline
\end{tabular}

Sumber: FEB Untan, 2017

Rekapitulasi jumlah mahasiswa dari setiap nilai-nilai yang diperoleh dapat terlihat, pada mata kuliah PA 1 dan AKM 1 mahasiswa yang memperoleh nilai A dengan kategori sangat memuaskan jumlahnya lebih banyak dari pada mahasiswa yang memperoleh nilai B, C, dan D yaitu masing-masing sebanyak 89 mahasiswa untuk PA 1 dan 93 mahasiswa untuk AKM 1 dari 232 mahasiswa yang dijadikan sampel. Ini bisa mengindikasikan bahwa materi yang diterima pada PA 1 dan AKM 1 lebih banyak bisa mahasiswa pahami dibandingkan dengan mata kuliah PA 2 dan AKM 2. Sementara itu, mata kuliah PA 2 dan AKM 2 mahasiswa lebih banyak memiliki nilai B dengan kategori memuaskan dibandingkan dengan nilai yang lainnya.

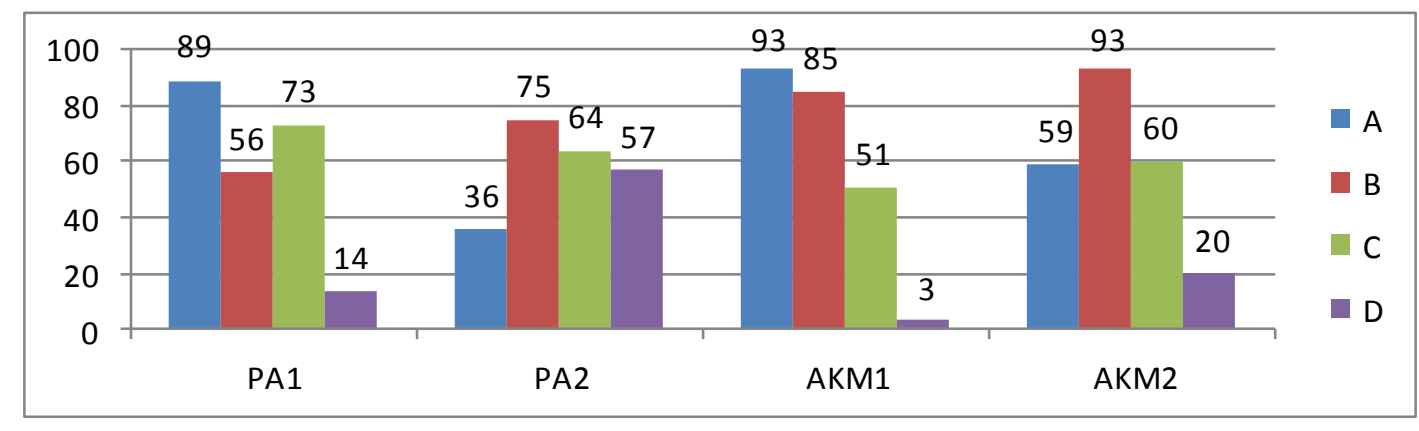

Gambar 2. Rekapitulasi Nilai Mahasiswa Berdasarkan Mata Kuliah

Sumber: FEB Untan, 2017 
Gambar 2 menggambarkan empat mata kuliah yang diambil oleh mahasiswa, mata kuliah AKM 1 adalah mata kuliah yang paling banyak menghasilkan nilai A bagi mahasiswa sedangkan AKM 2 adalah mahasiswa yang paling banyak mendapatkan nilai B dan paling banyak memperoleh nilai D dibandingkan dengan mata kuliah yang lainnya.

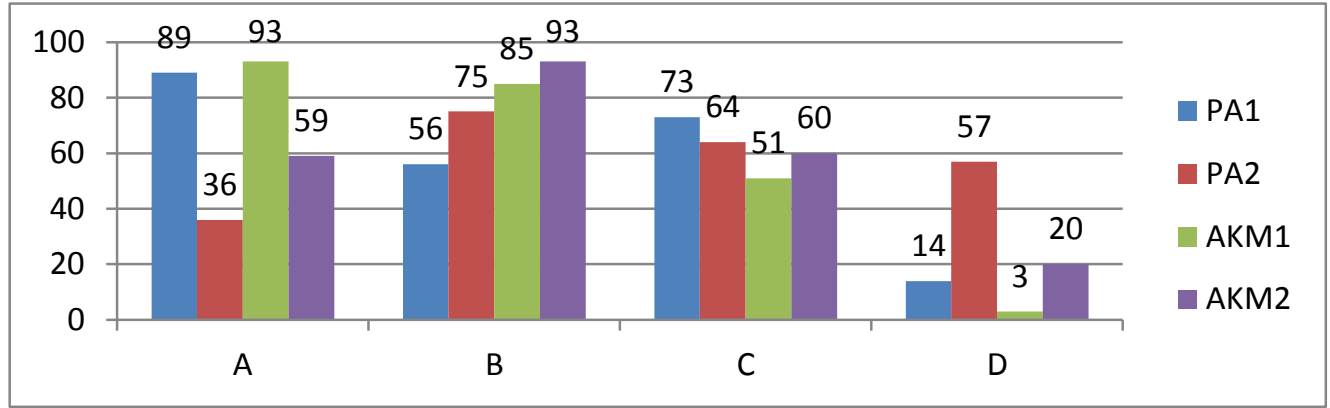

Gambar 3. Rekapitulasi Jumlah Mahasiswa Berdasarkan Kategori Nilai

Sumber: FEB Untan, 2017

Kategori yang memiliki nilai A paling banyak didapat mahasiswa yang mengambil mata kuliah AKM 1 dan mahasiswa yang memiliki nilai D paling sedikit pada mata kuliah ini. Hal ini menunjukkan mahasiswa memiliki tingkat pemahaman yang lebih baik pada mata kuliah AKM 1 dibandingkan tiga mata kuliah lainnya.

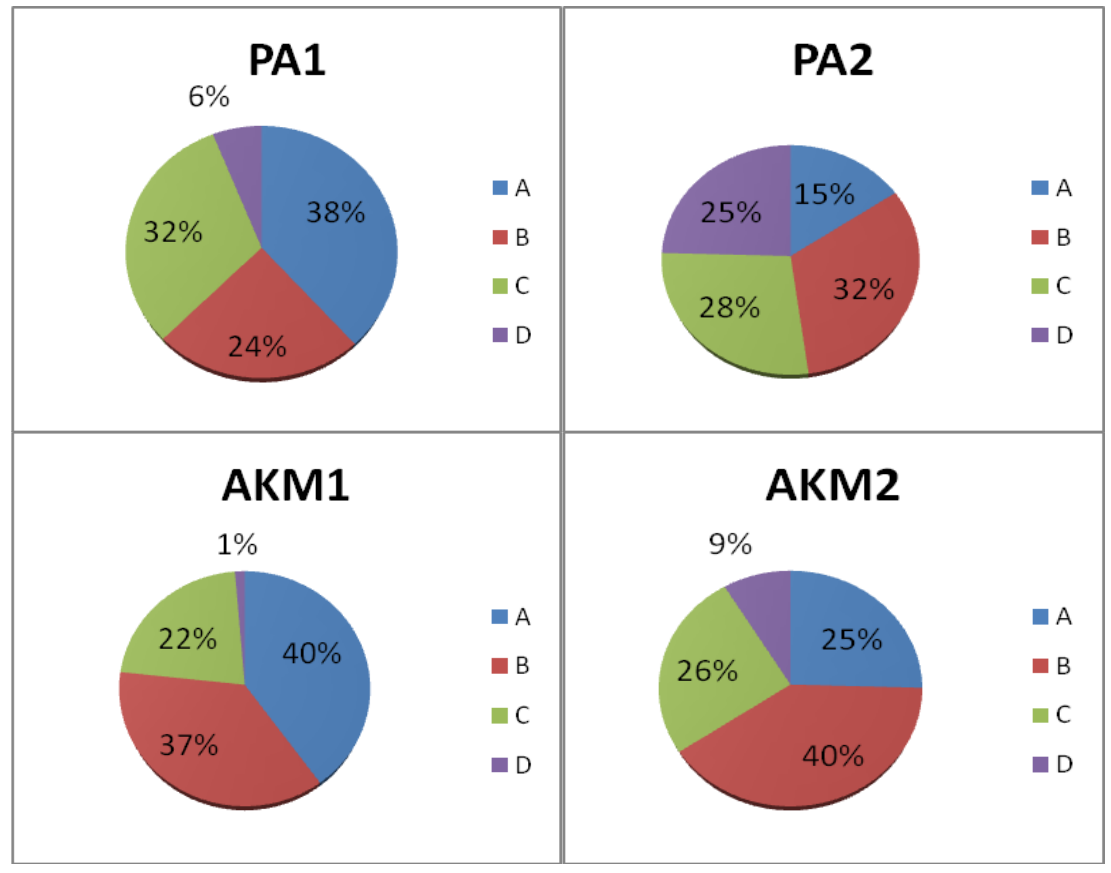

Gambar 4. Kontribusi Nilai Berdasarkan Mata Kuliah

Sumber: FEB Untan, 2017 
Gambar 4 menunjukkan rata-rata nilai dari keempat mata kuliah yang dijadikan indikator dalam tingkat pemahaman akuntansi mahasiswa dominan berada pada kategori nilai A dan B artinya rata-rata nilai dari keempat mata kuliah tersebut adalah memiliki predikat sangat memuaskan dan memuaskan. Sehingga dapat kita tarik kesimpulan sementara bahwa rata-rata nilai yang mahasiswa peroleh adalah nilai dengan kategori $\mathrm{B}$ dengan predikat memuaskan. Pernyataan ini haruslah dilakukan pengujian lebih lanjut agar kesimpulan sementara ini dapat dibuktikan.

Tabel 4. Rekapitulasi Jumlah Mahasiswa Berdasarkan Program (dalam orang)

\begin{tabular}{|c|c|c|c|c|c|c|c|c|c|c|c|c|c|c|c|c|c|}
\hline \multirow{2}{*}{ No } & \multirow{2}{*}{ Program } & \multicolumn{4}{|c|}{ PA1 } & \multicolumn{4}{|c|}{ PA2 } & \multicolumn{4}{|c|}{ AKM1 } & \multicolumn{4}{|c|}{ AKM2 } \\
\hline & & $\mathbf{A}$ & B & $\mathbf{C}$ & D & $\mathbf{A}$ & B & $\mathbf{C}$ & D & $\mathbf{A}$ & B & C & D & $\mathbf{A}$ & B & C & D \\
\hline 1 & $\mathrm{R}$ & 63 & 28 & 22 & 12 & 25 & 47 & 22 & 31 & 60 & 42 & 21 & 2 & 36 & 44 & 31 & 15 \\
\hline 2 & & 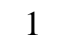 & 3 & 7 & 2 & 1 & 0 & 3 & 9 & 4 & r & 3 & & 5 & 5 & 2 & 1 \\
\hline 3 & PPAPK & 25 & 25 & 44 & 0 & 10 & 28 & 39 & 17 & 29 & 38 & 27 & 0 & 18 & 44 & 27 & 4 \\
\hline
\end{tabular}

Sumber: FEB Untan, 2017

Tabel 4 menunjukkan mahasiswa jurusan akuntansi Program Regular A FEB Untan lebih dominan dalam memperoleh nilai A dan B dibandingkan dengan program lain. Lain halnya dengan mahasiswa jurusan akuntansi dari Program PPAPK lebih dominan memperoleh nilai $\mathrm{B}$ dan $\mathrm{C}$ dibandingkan dengan program yang lainnya pada nilai mata kuliah akuntansi dasar yang dijadikan indikator dalam tingkat pemahaman akuntansi mahasiswa. Sehingga ada dugaan sementara bahwa terdapat perbedaan tingkat pemahaman akuntansi mahasiswa jurusan akuntansi dari setiap Program, yaitu Reguler A, Kelas Internasional dan PPAPK.

Tabel 5. Karakteristik Nilai Mata Kuliah Berdasarkan Gender (dalam Orang)

\begin{tabular}{llccccccccc}
\hline & \multicolumn{8}{c}{ Kategori } \\
\cline { 3 - 10 } No & Mata Kuliah & \multicolumn{1}{c}{ A } & \multicolumn{1}{c}{ B } & \multicolumn{1}{c}{ C } & \multicolumn{2}{c}{ D } \\
\cline { 2 - 10 } & Lk & Pr & Lk & Pr & Lk & Pr & Lk & Pr \\
\hline 1 & PA1 & 27 & 62 & 17 & 39 & 33 & 40 & 7 & 7 \\
2 & PA2 & 11 & 25 & 20 & 55 & 24 & 40 & 29 & 28 \\
3 & AKM1 & 25 & 68 & 35 & 50 & 22 & 29 & 2 & 1 \\
4 & AKM2 & 16 & 43 & 39 & 54 & 17 & 43 & 12 & 8 \\
\hline
\end{tabular}

Sumber: FEB Untan, 2017

Berdasarkan gender dari empat mata kuliah yang dijadikan indikator dalam tingkat pemahaman akuntansi, mahasiswa memiliki nilai dengan kategori A lebih banyak diperoleh mahasiswa yang bergender perempuan dibanding dengan laki -laki. Sementara itu, jika dilihat dari nilai dengan kategori nilai D mahasiswa bergender laki-laki lebih tidak dominan memperoleh nilai D dibandingkan mahasiswa bergender perempuan karena relatif sama antara mahasiswa yang bergender laki-laki dengan perempuan.

Nilai untuk mata kuliah PA 2 yang memiliki kategori D sangat banyak jumlahnya baik berdasarkan gender laki-laki dan perempuan dimana masing-masing sebanyak 29 
dan 28 mahasiswa. Lain halnya dengan mata kuliah PA1, AKM 1 dan AKM 2 jumlahnya tidak terlalu banyak yaitu masing-masing pada mata kuliah PA 1 sebanyak 7 mahasiswa, mata kuliah AKM 12 dan 1 mahasiswa dan AKM 2 masing- masing 12 dan 8 mahasiswa. Jadi dari jumlah mahasiswa berdasarkan mahasiswa yang memperoleh nilai dengan kategori D tidak dapat dijadikan acuan bahwa mahasiswa bergender laki-laki kurang paham dibandingkan mahasiswa bergender perempuan. Tapi jika dilihat dari jumlah sampel mahasiswa laki-laki yaitu sebesar 84 mahasiswa jumlah 29 mahasiswa yang memiliki nilai kategori D merupakan termasuk jumlah yang banyak. Dugaan yang timbul dari analisis data yang dilakukan adalah terdapat perbedaan tingkat pemahaman akuntansi mahasiswa di FEB Untan berdasarkan gender, sehingga harus dilakukan pengujian lebih lanjut mengenai dugaan tersebut.

\subsection{Hasil Pengujian dan Pembahasan}

Pengujian hipotesis pada penelitian ini menggunakan uji One Way ANOVA untuk melihat perbedaan tingkat pemahaman akuntansi mahasiswa dari Program Reguler A, Program PPAPK dan Program Kelas Internasional yang ada di FEB UNTAN dan uji Independent Samples Test untuk melihat perbedaan tingkat pemahaman akuntansi mahasiswa FEB Untan berdasarkan gender. Sebelumnya sudah terlebih dahulu dilakukan uji homogenitas untuk menguji kesamaan varian. Hasil dari pengujian hipotesis tersebut adalah sebagai berikut:

Tabel 6. Hasil Pengujian Hipotesis

\begin{tabular}{|c|c|c|c|c|}
\hline No & Hipotesis $\left(\mathbf{H}_{\mathbf{a}}\right)$ & Nilai Uji & Prob & $\begin{array}{c}\text { Keputusan } \\
\text { Hipotesis }\end{array}$ \\
\hline 1 & $\begin{array}{l}\mathrm{H}_{\mathrm{a} 1}: \text { Ada perbedaan tingkat pemahaman } \\
\text { akuntansi mahasiswa dari Program Reguler A, } \\
\text { Program PPAPK dan Program Kelas } \\
\text { Internasional yang ada di FEB UNTAN }\end{array}$ & 4,934 & 0,008 & $\begin{array}{c}\mathrm{H}_{\mathrm{a} 1} \text { diterima dan } \\
\mathrm{H}_{\mathrm{o}} \text { ditolak }\end{array}$ \\
\hline 2 & $\begin{array}{l}\mathrm{H}_{\mathrm{a} 2} \text { : Ada perbedaan tingkat pemahaman } \\
\text { akuntansi mahasiswa berdasarkan gender }\end{array}$ & 0,016 & 0,898 & $\begin{array}{c}\mathrm{H}_{\mathrm{a} 2} \text { ditolak dan } \\
\mathrm{H}_{\mathrm{o}} \text { diterima }\end{array}$ \\
\hline
\end{tabular}

Sumber: Hasil Olahan, 2017

Hasil pengujian hipotesis pertama $\left(\mathrm{H}_{\mathrm{a} 1}\right)$ menerima atau mendukung dugaan sementara dari penelitian ini yang menyatakan bahwa terdapat perbedaan tingkat pemahaman akuntansi mahasiswa jurusan akuntansi dari setiap program, yaitu Program Reguler A, Kelas Internasional dan PPAPK. Keputusan ini dilihat dari nilai $\mathrm{F}$ hitung yang diperoleh yaitu sebesar 4,934 lebih besar nilainya dari pada $\mathrm{F}$ tabel yaitu sebesar 3,035. Nilai signifikansi pengujian hipotesis lebih kecil dibandingkan dengan nilai taraf signifikansi 0,05. Dengan demikian dapat disimpulkan bahwa dugaan yang menyatakan adanya perbedaan antara mahasiswa Program Reguler A, Kelas Internasional dan PPAPK dalam tingkat pemahaman akuntansi dapat diterima atau dengan kata lain $\mathrm{H}_{\mathrm{a}}$ 
diterima dan $\mathrm{H}_{\mathrm{o}}$ ditolak. Hal ini terjadi bisa disebabkan oleh kualitas input yang berbeda, sehingga tingkat pemahaman dan motivasi dalam menerima materi perkuliahan juga berbeda.

Pengujian hipotesis kedua $\left(\mathrm{H}_{\mathrm{a} 2}\right)$ menolak dugaan yang menyatakan adanya perbedaan tingkat pemahaman akuntansi mahasiswa berdasarkan gender, artinya tidak ada perbedaan antara tingkat pemahaman akuntansi bagi mahasiswa berjenis kelamin laki-laki ataupun berjenis kelamin perempuan. Ini dibuktikan dengan hasil pengujian nilai hipotesis dari uji $\mathrm{F}$ hitung yang menunjukkan nilainya lebih besar dari pada $\mathrm{F}$ tabel yaitu sebesar $0,016<2,256$ dan nilai signifikasinya lebih besar dibandingkan dengan taraf signifikasi $0,05(0,898>0,05)$. Sehingga dapat ditarik kesimpulan bahwa dugaan yang mengatakan bahwa ada perbedaan tingkat pemahaman akuntansi bagi mahasiswa berjenis kelamin laki-laki ataupun berjenis kelamin perempuan tidak dapat didukung atau diterima. Temuan ini sejalan dengan hasil penelitian Mirawati (2015) yang juga menemukan tidak terdapat perbedaan pemahaman akuntansi antara mahasiswa berjenis kelamin laki-laki dengan perempuan. Melihat dari hasil tersebut maka dapat dikatakan bahwa tingkat pemahaman akuntansi mahasiswa tidak dapat ditentukan berdasarkan gender. Karena tingkat pemahaman seseorang bisa diperoleh melalui motivasi seseorang dalam memperoleh sesuatu yang mereka inginkan, sehingga bagi yang memiliki motivasi yang tinggi untuk memiliki tingkat pemahaman yang tinggi dan baik pastilah akan melakukan usaha dalam mencapai apa yang diinginkan.

\section{SIMPULAN}

Hasil dari temuan penelitian ini adalah temuan pertama, hasil pengujian hipotesis kedua $\left(\mathrm{H}_{\mathrm{a} 1}\right)$ menerima atau mendukung dugaan sementara dari penelitian ini yang menyatakan bahwa terdapat perbedaan tingkat pemahaman akuntansi mahasiswa jurusan akuntansi dari setiap Program, yaitu Reguler A, Kelas Internasional dan PPAPK. Keputusan ini dibuktikan dengan nilai $F$ hitung yang diperoleh yaitu sebesar 4,934 lebih besar nilainya dari pada $\mathrm{F}$ tabel yaitu sebesar 3,035. Nilai signifikansi pengujian hipotesis lebih kecil dibandingkan dengan nilai taraf signifikansi 0,05. Sementara itu, pengujian hipotesis kedua $\left(\mathrm{H}_{\mathrm{a} 2}\right)$ menolak dugaan yang menyatakan adanya perbedaan tingkat pemahaman akuntansi mahasiswa berdasarkan gender. Ini dibuktikan dengan hasil pengujian nilai hipotesis dari uji $\mathrm{F}$ hitung yang menunjukkan nilainya lebih besar dari pada $\mathrm{F}$ tabel yaitu sebesar $0,016<2,256$ dan nilai signifikasinya lebih besar dibandingkan dengan taraf signifikasi 0,05 $(0,898>0,05)$.

Penelitian ini dapat dikembangkan agar lebih bermanfaat dalam upaya peningkatan kualitas output dari FEB Untan khususnya jurusan akuntansi. Selain itu, dirasakan perlu untuk menjadikan hasil penelitian ini bahan dan informasi tambahan dalam pertimbangan pengambilan sebuah kebijakan untuk terus melakukan perbaikan dan peningkatan kualitas dari mahasiswa jurusan akuntansi untuk lebih memiliki tingkat 
pemahaman akuntansi yang lebih baik, dengan harapan mahasiswa dapat menjadi bekal dalam menghadapi dunia kerja yang serba harus mampu untuk bersaing.

Penelitian ini dapat dikembangkan menjadi penelitian berikutnya yang berbeda dengan menggunakan variabel-variabel tambahan lainnya serta dapat juga menggunakan kuesioner untuk lebih bisa menggali dan menganalisis lebih dalam mengenai kendala atau hambatan dalam pemahaman akuntansi dari sisi mahasiswa yang dijadikan sampel, karena keterbatasan dalam penelitian ini tidak dapat memberikan analisis mengenai kendala yang dihadapi mahasiswa dalam memahami akuntansi. Selain itu, dapat juga melakukan penambahan jumlah sampel dan perluasan wilayah sampel sehingga bisa lebih baik hasilnya, misalnya dengan membandingkan antar universitas. Penelitian berikutnya dapat melakukan pengujian hipotesis dengan alat analisis yang lainnya misalnya dengan menggunakan analisis regresi atau pun yang lainnya untuk mengetahui lebih detail dari variable-variabel yang berkaitan dengan peningkatan atau yang mempengaruhi tingkat pemahaman terhadap akuntansi.

\section{REFERENSI}

Aditya, E. M. (2011). Analisis Tingkat Pemahaman Mahasiswa Akuntansi Terhadap Konsep Dasar Akuntansi (Analysis about Understanding Students Majoring In Accounting of the Basic Concepts of Accounting) Studi Empiris pada Mahasiswa S1 Jurusan Akuntansi PTS "X” Semarang yang Beras. Fokus Ekonomi, 6(1), 40-48.

Biduri, S. (2016). Pengaruh Pemahaman Mahasiswa Akuntansi Terhadap Konsep Dasar Akuntansi dengan Latar Belakan Sekolah Menengah yang Berbeda pada Universitas Muhammadiyah Sidoarjo - Jawa Timur. Prosiding Seminar Nasional Ekonomi Dan Bisnis \& Call for Paper FEB UMSIDA 2016, 512 - 527.

Budhiyanto, S. J., \& Nugroho, I. P. (2004). Pengaruh Kecerdasan Emosional terhadap Tingkat Pemahaman Akuntansi. Jurnal Ekonomi Bisnis, X(2), 260-281.

Goleman, D. (2000). Working with Emotional Intelligence. (Terjemahan Alex Tri kantjono W.). Jakarta: PT Gramedia Pustaka.

Hanifah, \& Abdullah, S. (2001). Pengaruh Prilaku Belajar terhadap Prestasi Akademik Mahasiswa Akuntansi. Media Riset Akuntansi, Auditing Dan Informasi, 1(3), 6386.

Harefa, A. (2000). Perlukah Sekolah/Universitas Dipertahankan?Buletin Indonesia Belajarlah. Jakarta: Indonesia School of Life.

Kusuma, B. H., \& Bangun, N. (2011). Analisis Pemahaman Mahasiswa Akuntansi Terhadap Konsep Aset, Kewajiban dan Ekuitas. Jurnal Bisnis Dan Akuntansi, 13(3), $183-194$.

Machfoedz, M. (1999). Studi Persepsi Mahasiswa terhadap Profesionalisme Dosen Akuntansi. JAAI FE UII.

Martono, Nanang, E. P., Mintarti, \& Rostikawati, R. (2009). Perbedaan Gender Dalam Prestasi Belajar Mahasiswa UNSOD. Jurusan Sosiologi FISIP Universitas Jenderal 


\section{Soedirman Purwokerto.}

Mawardi, M. C. (2011). Tingkat Pemahaman Mahasiswa Akuntansi Terhadap Konsep Dasar Akuntansi di Perguruan Tinggi Negeri di Kota Malang. IQTISHODUNA, $8(1), 1-19$.

Mirawati. (2015). Analisis Tingkat Pemahaman Mahasiswa Akuntansi Terhadap Konsep Aset, Liabilitas, dan Ekuitas di Perguruan Tinggi Kota Tanjungpinang. Prodi Akuntansi Fakultas Ekonomi Universitas Mariti Raja Ali Haji (UMRAH) Tanjungpinang, 1-17.

Novius, A. (2010). Analisis Pemahaman Mahasiswa Akuntansi dalam Menghadapi Mata Kuliah Dasar-dasar Akuntansi (Studi Pada Mahasiswa Akuntansi - S1 Universitas Islam Negeri Sultan Syarif Kasim Riau). Fokus Ekonomi, 5(2), 44-60.

Pirmohamed, S., Debowska, A., \& Boduszek, D. (2017). Gender Differences In The Correlates of Academic Achievement Among University Students. Journal of Applied Research in Higher Education, 9(2), 313-324. https://doi.org/10.1108/JARHE-03-2016-0015.

Prakarsa, W. (1996). Transpormasi Pendidikan Akuntansi Menuju Globalisasi. Konvensi Nasional Akuntansi III (Konvensi N). Jakarta: Ikatan Akuntansi Indonesia.

Rusmita, S. (2012). Analisis Tingkat Pemahaman Mahasiswa Akuntansi terhadap Konsep Dasar Akuntansi Berdasarkan Asal Sekolah. Jurnal Ekonomi Bisnis Dan Kewirausahaan 2012, 3(1), 85-94.

Sari'i, M., Irsadsyah, M., \& Nasrullah, D. (2010). Analisis Tingkat Pemahaman Mahasiswa Akuntansi Terhadap Konsep Dasar Akuntansi. Simposium Nasional Akuntansi XIII.

Suwardjono. (1992). Akuntansi Pengantar: Konsep Proses Penyusunan Laporan Pendekatan Sistem dan Terpadu. Yogyakarta: BPFE.

Trisniwati, E. I., \& Suryaningsum, S. (2003). Pengaruh Kecerdasan Emosional Terhadap Tingkat Pemahaman Akuntansi. SIMPOSIUM NASIONAL AKUNTANSI VI, Surabaya, (16 - 17 Oktober 2003), 1073 - 1091.

Zoghi, M., Kazemi, S. A., \& Kalani, A. (2013). The Effect of Gender on Language Learning. Journal of Novel Applied Sciences, Journal-20. 